\title{
The Influence of HR Competencies and Entrepreneurs' Skills on Sasirangan MSMEs' Business Performance in Banjarmasin Municipality
}

\author{
Meiske Claudia $^{1, *}$, Rusniati $^{2}$ \\ ${ }^{1}$ Faculty of Economics and Business, Universitas Lambung Mangkurat, Banjarmasin, Indonesia \\ ${ }^{2}$ Faculty of Economics and Business, Universitas Lambung Mangkurat, Banjarmasin, Indonesia \\ ${ }^{*}$ Corresponding author: mclaudia@ulm.ac.id
}

\begin{abstract}
This study aims to determine and analyze the influence of human resource (HR) competencies and entrepreneurs' skills on Sasirangan MSMEs' business performance in Banjarmasin Municipality. The empirical data would be the basis for the formulation of suggestions for Sasirangan entrepreneurs so that they could continously improve their HR competencies and their own entrepreneurs' skills in order to maintain business continuity through their good business performance. This research was conducted by survey method. Primary data were collected through questionnaires. Research's population were thirty-three (33) MSMEs located in two (2) Sasirangan fabric centers (Sungai Jingah and Seberang Mesjid). The whole population were taken as samples using saturated sampling technique. Data processing was carried out using descriptive statistical analysis techniques and multiple linear regression. The results of the study indicated that HR competencies had negative insignificant effect on Business Performance while Entrepreneurs' Skills had positive significant effect on Business Performance. The higher the Entrepreneurs' Skills of the Sasirangan MSMEs' owners, the higher their business performance. Further research can explore other new variables such as entrepreneurial intentions, interests, behavior, education and competencies as the antecedents to Sasirangan MSMEs' success.
\end{abstract}

Keywords: HR Competencies, Entrepreneurs'Skills, Business Performance.

\section{INTRODUCTION}

One of the leading driving forces in economic development is micro, small and medium enterprises (MSMEs). MSMEs have a significant role in the economy. This business is labor intensive, uses simple technology, and is able to absorb a lot of labor. These specific characteristics of MSMEs can create equal distribution of business opportunities and income distribution [1]. micro-small-medium enterprises are a sub-sector of economic activity that play an important role in strengthening the macroeconomic structure [2]. The existence of MSMEs has enabled our country to face trade globalization such as the China ASEAN Free Trade Area (CAFTA) and the Asean Economic Community (AEC).

Law No. 20 of 2008 concerning Micro, Small and Medium Enterprises legally declare micro, small and medium enterprises. Based on the Law, limits are given to MSMEs based on certain categories. The category of micro, small and medium enterprises is a stand-alone productive business managed by individuals or business entities that have a net worth

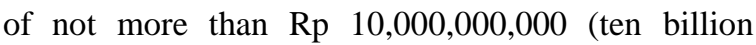
rupiahs) including land and buildings for business premises and sales proceeds not more than $\mathrm{Rp}$ 50,000,000,000, - (fifty billion rupiah).

There is a difference meaning of Business Performance between small companies and large companies. Good business performance for companies classified as micro, small and medium is an important issue that needs to be discussed considering fast development of MSMEs in Banjarmasin City [3]. According to the Head of the Office (Kadis) of MSMEs Cooperatives in Banjarmasin City, the MSMEs' business performance are said to increase if they transform from micro to small businesses and small businesses to medium enterprises. Meanwhile, use annual sales, annual income and number of 
employees as indicators to determine the level of development of MSMEs' performance [3].

Increasing complexity of business competition and rapid technological developments demand a greater role of Human Resource Management. The important role of HR as a source of organization competitive advantage is increasingly being recognized as its ability to anticipate changes that occur in the business environment. High competencies Human Resources can support the improvement of employee performance and contribute in determining company's future. Competencies is the ability and willingness to perform tasks with effective performance.

Several studies have been conducted regarding Human Resource Competencies (HR) and Entrepreneurs' Skills and their influence on Business Performance. The findings were varied. One of study results from Sidharta stated that knowledge, skills and abilities were factors that had a dominant influence on HR competencies [4].

Ardiana also stated in their study that knowledge is a person's mastery of science and technology and obtained through a learning process and experience during his life. A skill is a special capacity to physically manipulate an object. Ability is the capacity of an individual to do various tasks in a job. The three indicators of HR competencies have a significant influence on MSMEs' performance which affects MSMEs' competitiveness [5].

In addition to HR competencies, another variable that also has an influence on MSMEs' business performance success is the owners' entrepreneurs' skills. These entrepreneurs' skills, can be measured from 5 indicators, namely creative thinking skills, decision-making skills, leadership skills, managerial skills, and interpersonal skills [6].

This study examined and analyzed the influence between variables so that the results can broaden the horizons of Sasirangan business owners. It is expected they become more capable in managing their HR competencies and improving their entrepreneurs' skills which result in satisfactory business performance and increase their business continuity.

\subsection{Research Questions}

1. Do HR Competencies and Entrepreneurs' Skills simultaneously affect Sasirangan MSMEs' Business Performance?

2. Does HR Competency affect Sasirangan MSME's Business Performance?
3. Does Entrepreneurs' Skills affect Sasirangan MSME's Business Performance?

\subsection{Literature Review}

Competency is an ability to carry out or perform a job or task based on skills and knowledge and supported by the work attitude required by the job [7]. Knowledge is a person's mastery of science and technology and is obtained through a learning process and experience during one's life. A skill is a special capacity to physically manipulate an object. Ability is the capacity of an individual to do various tasks in a job [5].

Competency shows skills or knowledge are characterized by professionalism in a particular field as the most important thing to excel in that field. Competency is an individual characteristic that underlies performance or behavior in the workplace. A person's performance on a job is influenced by:

a. Knowledge, ability and attitude

b. Work style, personality, interests/interests, basic principles, attitude values.

c. Trust and leadership style [7].

Superior performers are those who demonstrate high sclae competencies with better results. Therefore, competency is a fundamental characteristic of each individual with certain criteria which resulted in superior performance. Competency is one of human resources aspects that is very influential on business performance [4]. This relates to the type of work, where for certain types of work - certain standards of competency are required. The determination of these competencies standard relates to the extent to which the ability possessed by the individual is related to his skills, knowledge and work ability. HR competencies ( knowledge, attitudes and skills) which connected to one another should be trained and developed in order to produce the best performance in business management.

Competency is the basic foundation of people's characteristics and indicates a way of behaving or thinking, equating situations and supporting them for a long period of time [8]. There are five (5) types of competency characteristics, namely motives, traits, self-concept, knowledge and skills. The conclusion from several definitions of competency is an ability possessed by a person as a human resource, which can be improved and underlies a person in working or behaving.

The development of competency as a concept and practice in management cannot be separated from the historical development of Human Resource 
Management (HRM) itself. Sidartha predict factors that have a dominant influence on competency, namely knowledge, skills and abilities [4]. Furthermore, competency is an ability to carry out or perform a job or task based on skills and knowledge and supported by the work attitude demanded by the job [7].

Moeheriono defines competencies as a person's underlying characteristics related to the effectiveness of individual performance in his work, where these characteristics consist of knowledge and skills. Spulber argues that competency can be defined as the ability of a company in many different activities, such as research, development, production, transportation, and transactions [9] [10].

Competency is the skills or abilities needed by the organization for the success of achieving goals. Robbins further stated that there are three skills that must be possessed by HR, namely:

1. Technical skills, is the ability to apply special knowledge or specialization skills. This ability is acquired through formal education and developed on the job.

2. Human skills, which include the ability to work together, understand and motivate others, both individually and in groups.

3. Conceptual skills, namely the mental ability to analyze and diagnose complex situations. At the time of decision making there is a demand to find the location of the problem, identify various alternatives to solve the problem, and be able to choose the best alternative [11].

Individual competency is described as the basic characteristics of individuals who use their personality most deeply and can influence their behavior when facing work which ultimately affects the ability to deliver work performance. The scope of competency is as follows;

1. Intellectual competency is the character of attitudes and behavior or individual will and intellectual in the form of knowledge, skills, professional understanding, contextual understanding, and others that are relatively stable when facing problems at work, which are formed by the synergy of character, self-concept, internal motivation and contextual knowledge capacity.

2. Emotional competency is the character of attitudes and behavior or the willingness and ability to control oneself and understand the environment objectively and morally so that the emotional pattern is relatively stable when facing work problems, which is formed through the synergy of character, self-concept, internal motivation and emotional capacity.

3. Social competency is the character of attitudes and behavior or the willingness and ability to build cooperative nodes with other people who are relatively stable when facing work problems that are formed through the synergy of character, selfconcept, internal motivation and the capacity of contextual social knowledge [8] [12].

From the description above, it can be concluded that competency is the ability possessed by an organization in achieving business success. The business owner has their employees as competent HRs whose ability to carry out tasks in the workplace by applying their knowledge supported by skills and abilities in accordance with their role.

\subsection{Entrepreneurs Skills}

Skills are the ability to use reason, thoughts, ideas and creativity in doing, changing and making things more meaningful so as to produce valuable work. Better skills gained through training to increase ones' abilities so that they become experts. An entrepreneur is someone who actualizes his potential in creative and innovative thinking to create new and value-added products.

In addition to the provision of abilities, an entrepreneur also needs to have knowledge and skills. The knowledge that entrepreneurs must have includes: 1) knowledge about the business to be started and the existing business environment 2) knowledge about roles and responsibilities 3) knowledge about management and business organization. The provision of skills that must be possessed by entrepreneurs includes: 1) the provision of conceptual skills in managing strategies and calculating risks, 2) the provision of creative skills in creating value-added, 3 ) the provision of skills in leading and managing, 4) the provision of communication and interaction skills, 5) the provision of technical business skills that will be carried out [13]. It can be concluded that Entrepreneurs' Skills is the ability to use ideas and creativity through training and learning to create and produce value added to for the benefit of oneself and others.

\subsection{Business Performance}

Business performance, especially MSMEs, is an important issue that has often been debated in recent years because of the growing development of MSMEs in Indonesia. According to Keats and Bracker in [3], performance has a different meaning for small 
companies than large companies. Pfeffer and Salancik argue that company performance is defined as the company's ability to make acceptable actions and results. However, company performance must be conceptualized and operationalized, and can be measured in various ways [14].

Ramanujam, Venkatraman \& Camilu, Reid \& Smith state that the effectiveness of performance can be measured by what goals the company has designed and whether those goals have been achieved [3]. According to them, the measurement of performance itself must be based on financial and non-financial measurements. Pushpakumari and Wijewickrama use both financial and non-financial such as annual sales, annual income, and number of employees [3].

A company's business performance can be measured through a combination of financial and nonfinancial measures including annual sales growth, annual profit growth, employee growth, market share, and the size of the business investment. This performance variable was adopted from Watanabe [3]. It was found that most MSMEs in Sri Lanka do not manage financial statements well and are reluctant to disclose data even though they are available [15]. Therefor owners/managers were asked to indicate the trend of each business performance indicators over the last three years as "Strongly increased" to "Strongly decreased" using a 5-point scale.

Business Performance can be measured by determining whether the company is experiencing an increase or growth in its business. This study uses business performance indicators based on financial and non-financial aspects, namely annual sales, annual income and number of workers.

\subsection{Previous Research}

1. Hamzani (2014) study found HR Competencies can be classified as good category while the implementation of accounting information systems can be classified in category as fairly good. The results show HR Competencies (H1) significantly affects the performance of MSMEs while the implementation of accounting information systems (H2) does not significantly affect the performance of MSMEs [16].

2. Ardiana, Brahmayanti \& Subaedi (2010) found that the knowledge variable has a negative value and is very small or insignificant to performance, while the skill and ability variables have a significant influence [5].

3. Paramitha (2015) found that individual competencies, entrepreneurial orientation and competitors have a positive effect on competitive advantage with product quality as a mediating variable [17].

4. Irawan \& Mulyadi (2016) found a positive and significant influence of Entrepreneurial Skills on Business Performance. The result showed that the higher the Entrepreneurial Skills, the higher its influence on business success [18].

5. Pushpakumari \& Watanabe research show that the performance of SMEs varies according to the choice of strategic orientation adopted by the owner-manager [3].

6. Gerli, Gubitta \& Tognazzo (2011) study results show that the entrepreneurial competency portfolio has an impact on organizational performance. In particular, competencies such as Efficiency Orientation, Planning, Persuasiveness, Confidence, Organizational Awareness, Directing others, Teamwork, Leadership and Benchmarking are linked to higher company performance. This study concludes the importance of entrepreneurs developing some specific competencies to get higher performance [19].

7. Al Mamun, Fazal \& Muniady (2019) study revealed that Entrepreneurial Skills, market orientation, and networking had a positive effect on entrepreneurial competencies. Then, entrepreneurial competencies, Entrepreneurial Skills and networking had a positive effect on company performance. The findings showed a significant mediating effect of entrepreneurial competencies on the relationship between Entrepreneurial Skills, market orientation and networking with firm performance [20].

8. Minai, Raza, Hashim, Zain \& Tariq (2018) proposed a framework to examine firm performance from the perspective of entrepreneurial education as the only independent variable and entrepreneurial competencies as a mediating variable. This paper is conceptualized on the basis of the theory underlying a resourcebased view in a small business context. It provides several useful implications for entrepreneurs in ensuring higher levels of entrepreneurial education and entrepreneurial competencies leading to better Small Business Performance [21].

9. Asyifa, Rakib, \& Tahir (2019) study found that entrepreneurial competencies variable has a positive and significant effect on business performance [22]. 
10. Wahyudiati (2017) study results showed that there was a positive influence (partially and simultaneously) from the financial aspect and HR competencies on the performance of MSMEs in Kasongan Village [23].

11. Sajilan, Tehseen, \& Adeyinka study found that very few of these SMEs were successful while most were operating at the survival stage and others were on the verge of collapse due to lack of entrepreneurial competencies which negatively impacted their performance. The findings also show that the performance of SMEs depends on internal and external factors, including financial and non-financial factors [24].

12. Wardana \& Utama findings showed that knowledge and skills, competencies have no significant effect on business performance. Ability is the only factor that has a positive significant impact on business performance and business performance has positive significant impact on its competitive advantage [25].

13. Sembiring (2016) in his research seeks to explore the influence of knowledge and skills of human resources on the culinary performance of Small and Medium Enterprises (SMEs) in Medan City, Indonesia. The results showed that HR knowledge and skills partially and simultaneously have a positive significant influence on the SMEs performance. The Human Resources skill factor has a greater impact on the performance of SMEs compared to the human resource knowledge factor [26].

14. Hurriyati, Razati, Sulastri, \& Putra in their research found that there is a strong significant influence of Entrepreneur Skills on business performance [27].

15. Abdul study showed that Entrepreneurial Skills have a significant influence on the growth of SMEs in Nigeria and the UK. Respondents in Nigeria and the UK agreed that creative thinking, problem solving and communication skills are essential for increasing sales and competitive advantage. In addition, respondents in Nigeria strongly agree that high-level creative thinking with minimal problem solving and communication skills will promote the growth of SMEs. In contrast, minority British entrepreneurs argue that great creative thinking and a balance between problem solving and communication skills are essential for the growth of SMEs [28].

\subsection{Conceptual Framework}

Based on the literature review and previous studies, the the conceptual framework for the influence of human resources competencies and entrepreneurs' skills on Sasirangan MSMEs' business performance in Banjarmasin Municipality is developed as shown in Figure 1.



Figure 1. The Influence of Human Resources Competencies and Entrepreneurs' Skills on Sasirangan MSMEs' Business Performance in Banjarmasin Municipality

Description : $\quad \longrightarrow$ The simultaneous effect

$\rightarrow$ The partial effect

\section{METHODOLOGY}

This research is an explanatory research which explains causal relationships that occurs between the independent variable and the dependent variable by testing the hypothesis [29]. The population in this study were all (33) Sasirangan business owners in Banjarmasin Municipality, which located in Sungai Jingah Village and Seberang Mesjid Village. The relatively small number of existing population data resulted in the using of saturated sampling.

This quantitative study was conducted in 2019. Primary data are collected from Sasirangan business owners' perception arranged on a numerical scale using a direct and closed ended questionnaire.

This study consisted of three variables, namely HR Competency (X1) and Entrepreneurial Skills (X2) as independent variables while the dependent variable is Business Performance (Y). For the purposes of this study, the research variables used were defined operationally as follows:

\section{HR Competency}

HR competency is the general perception of Sasirangan business owner to their employees' skill, 
knowledge and ability in carrying out their worksplace tasks in accordance with business field.

2. Entrepreneurs' Skills

Entrepreneurial skills are the ability of business owners to use their ideas and creativity to produce something that has value added for the benefit of themselves and others. Indicators of Entrepreneurs' Skills include:

a. Technical Skills, measured through skills in managing operations, beyond the basic production of products or services. Including the ability to manage supply chains and have knowledge of new technologies.

b. Management Skills, measured through planning and organizing skills, identifying customers and distribution channels, managing resources and the ability to manage in the right place and structure control systems. These skills include high-level skills, such as problem solving, the ability to build core abilities and the ability to deal with employees effectively.

c. Entrepreneurship skills. These skills include business planning, sensitivity to opportunities, business environment analysis and the ability to access external expertise.

d. Personal maturity skills. These skills include selfawareness, the ability to reflect on what happened, recognize and correct weaknesses, be responsible for solving problems and the ability to come up with solutions.

\section{Business Performance}

Business Performance is the condition of a company experiencing an increase or growth in terms of its line of business, which is measured by financial and non-financial indicators, namely annual sales, annual income and number of workers.

All of the variables in this study were measured using a 5 point Likert scale varies from choices "very low" scored 1 to "very high" scored 5 [30].

\section{RESULT \& DISCUSSION}

There were 33 respondents as Sasirangan business owners who participated in this study. Thirty respondents of Sasirangan business owner age ranging from 21-55 years old. They were in productive age in building a business and has quite a lot of experience in running a business

Characteristics of respondents based on gender showed that there were 9 male respondents and 24 female respondents. Based on the results of the interview, it was found that women were equiped with high skills and awareness in making sasirangan.
The tenure of business varies from 2 years to 32 years. There were 9 and 7 respondents whose business existence were in the second and third years. Almost $50 \%$ of the existing respondents have businesses that are still relatively new. The education level of Sasirangan MSMEs' owners varies from elementary school graduation to undergraduate level. However, the majority of the business owners have an education level equivalent to SMA/MA/SMK graduation.

The HR Competency variable consists of 3 dimensions with 10 question items. The dimensions consist of knowledge, skills and abilities. Respondents' responses to the HR competency variable have an average value of 4.15 . The highest average score is X1.10 with a Mean value of 4.33 . The Mean value is included in the very high category. The response of respondents who have the lowest average score of 3.76 is in $\mathrm{X} 1.1$.

The Entrepreneur's Skills variable consists of 4 dimensions with 23 question items. The dimensions consist of technical skills, management skills, entrepreneurial skills and personal maturity skills. Respondents' responses to the entrepreneurial skills variable have an average value of 3.98. The highest average score is X2.2 with a Mean value of 4.39. The Mean value is included in the very high category. The response of respondents who have the lowest average score of 3.64 is on $\mathrm{X} 2.18$.

The Business Performance variable consists of 3 dimensions with 6 question items. Its dimensions consist of annual sales, annual profits and number of workers. Respondents' responses to the business performance variable have an average value of 3.89. The highest average score is Y1 with a Mean value of 4.06. The Mean value is included in the very high category. The response of respondents who have the lowest average score of 3.55 is at Y6.

\subsection{Validity and Reliability Test}

The measurement of validity in this study uses the Pearson Correlation, which calculating the correlation between the scores of each item or statement item with the total score. The basis for decision making in the validity test are:

If $r$ count $>r$ table, it can be stated that the question items are valid. If $r$ count $<r$ table, it can be stated that the question item is not valid.

Through the determination of the $r$ table by looking at the distribution table of the $r$ table based on the DF of $\mathrm{N}-2=33-2=31$ with a significance of 0.05 , the $\mathrm{r}$ table value is 0.344 . From the results of data 
processing, it is known that the calculated $r$ value in $\mathrm{X} 1, \mathrm{X} 2$ and $\mathrm{Y}$ indicators are greater than the $\mathrm{r}$ table value of 0.344 , so it can be concluded that all statements on the HR Competency, Entrepreneurial Skills and Business Performance are valid.

Reliability test is a tool to measure a questionnaire which is an indicator of a variable or construct. The questionnaire is said to be reliable or reliable if the respondents' answers to these questions are consistent or stable from time to time. A construct or variable is called reliable if the Cronbach's Alpha value is $>0.70$ [31]. Based on the results of data processing, it is known that the value of Cronbach's Alpha variable X1 is $0.904, \mathrm{X} 2$ is 0.940 and $\mathrm{Y}$ is 0.950 . Each Cronbach's Alpha value $>0.70$, it can be concluded that all variables in this study were reliable.

\subsection{Classic Assumptions Test}

a. Normality Test

The results of the normality test with KolmogorovSmirnov showed the Asymp value. Sig. (2-tailed) of $0.943>0.05$, so it can be concluded that the data tested in this study were normally distributed.

\section{b. Multicollinearity Test}

The SPSS calculation shows that in this study there are no symptoms of multicollinearity, because all considerations and conditions for making multicollinearity test decisions are met, namely the tolerance value 0.10 or the same as the variance inflation factor (VIF) 10 (VIF value 3.787 with tolerance 0.264 ).

\section{c. Heteroscedasticity Test}

Detecting the presence or absence of heteroscedasticity is done by the Gletsjer method, by regressing the independent variable with the absolute value of the residual. If the significance value between the independent variable and the absolute residual is more than 0.05 , then there is no heteroscedasticity problem. The significance value of the HR Competency variable is $0.944>0.05$, meaning that there is no heteroscedasticity in the HR Competency variable. The significance value of the Entrepreneurial Skills variable is $0.750>$ from 0.05 , meaning that there is no heteroscedasticity in the Entrepreneurial Skills variable.

\section{d. Linearity Test}

The linearity test is used to see if the model specifications used are correct or not. Through linearity test, . should be linear, quadratic or cubic. This test method can be carried out by SPSS testing using the Test for Linearity with a significance level of $<0.05$ [31]. The significance value of all $\mathrm{X}$ variables $(\operatorname{sig} \mathrm{X} 1=0.001$ and $\operatorname{sig} \mathrm{X} 2=0.000$ is smaller than 0.05), which means that there is a linear relationship between the independent variables and the dependent variable.

Table 1. Result of Multiple Regression Analysis Test

\begin{tabular}{|l|c|c|c|c|}
\hline Variable & $\begin{array}{c}\text { Reg. } \\
\text { Coeff. }\end{array}$ & t count & Sig. & Result \\
\hline Constant & $-6,321$ & & & \\
\hline $\begin{array}{l}\text { HR } \\
\text { Competencies } \\
\text { X1) }\end{array}$ & $-0,063$ & $-0,272$ & 0,787 & $\begin{array}{c}\text { Not } \\
\text { significant }\end{array}$ \\
\hline $\begin{array}{l}\text { Entrepreneurs' } \\
\text { Skills (X2) }\end{array}$ & 0,351 & 3,031 & 0,005 & Significant \\
\hline $\begin{array}{l}\mathrm{t} \text { table } \\
\mathrm{R}\end{array}$ & $=1,697$ \\
$\begin{array}{l}\text { R Square } \\
\text { Adjusted R Square } \\
\text { Std. Error }\end{array}$ & $\begin{array}{l}=0,705 \\
=0,464 \\
=3,257\end{array}$ & $\begin{array}{l}\text { Fcount }=14,855 \\
\text { Sig F }=0,000 \\
\text { Ftable }=3,30\end{array}$ \\
\hline
\end{tabular}

Based on Table 1, the mathematically equation formula for the multiple linear regression function model is as follows:

$$
\begin{gathered}
\mathrm{Y}=+\mathrm{b} 1 \mathrm{X} 1+\mathrm{b} 2 \mathrm{X} 2+\mathrm{e} \\
\mathrm{Y}=-6.321+-0.063 \mathrm{X} 1+0.351 \mathrm{X} 2+3.257
\end{gathered}
$$

Based on these results, the value of each variable in the multiple linear regression model illustrates that:

1. $\mathrm{R}$ in multiple linear regression shows the value of multiple correlation, namely the correlation between two or more independent variables on the dependent variable. The $\mathrm{R}$ number obtained is 0.705 . The correlation value shows a high level of relationship because it is in the range of $0.600-$ 0.799 . This means that there is a high correlation of HR Competencies and Entrepreneurs' Skills on Business Performance.

2. R Square shows the coefficient of determination. $\mathrm{R}$ square value of 0.498 shows the percentage contribution of the influence of the variable HR Competencies (X1) and Entrepreneurs' Skills (X2 on Business Performance (Y) of $49.8 \%$ while the remaining $50.2 \%$ is influenced by other variables not examined in this study.

3. Adjusted R Square is $\mathrm{R}$ Square that has been adjusted. Adjusted R Square value of 0.464 also shows the contribution of the influence of the independent variable on the dependent variable which means $46.4 \%$, while the remaining $53.6 \%$ is explained by other reasons outside the research model.

4. The constant value is -6.321 . This shows that if the HR Competencies (X1) and Entrepreneurs' Skills (X2) variables are zero (none) then the Business Performance $(Y)$ value is -6.321 . 
5. Coefficient $X 1=-0.063$. The negative coefficient value on the HR Competencies variable (X1), indicates that there is a unidirectional influence.

6. Coefficient $\mathrm{X} 2=0.351$. The positive coefficient value on the Entrepreneurs' Skills variable (X2), indicates that there is a unidirectional effect, where if there is an increase in the Entrepreneurs' Skills variable (X2) by one unit, it will have an impact on increasing Business Performance (Y) by $35.1 \%$. That is, the better the entrepreneurs' skills, the better business performance will be.

7. Std. Error of the Estimate (SEE) is a measure of prediction error, with a value of 3,257 . This means that the error that occurs in predicting Business Performance is 3,257 .

\subsection{The Influence of HR Competencies and Entrepreneurs' Skills on Business Performance}

Based on the data in Table 2, the calculated $F$ value is 14,855 , while the $F$ table value can be seen in column df, where the numerator is 2 and the denominator is 31 , so that the $\mathrm{F}$ table value is 3.30 . Table 2 shows the value of Sig F is 0.000 . Based on calculated $\mathrm{F}$ value $>\mathrm{F}$ table, which is $14.855>3.30$ and the value of Sig. $0.000<0.05$, it can be said that the HR Competencies variable and the Entrepreneurs' Skills variable simultaneously affect Business Performance.

Table 2. Result of F test

\begin{tabular}{|c|l|c|c|c|c|c|}
\hline \multicolumn{2}{|c|}{ Model } & $\begin{array}{c}\text { Sum of } \\
\text { Squares }\end{array}$ & df & $\begin{array}{c}\text { Mean } \\
\text { Square }\end{array}$ & F & Sig. \\
\hline \multirow{2}{*}{1} & Regression & 315.131 & 2 & 157.565 & 14.855 & $.000^{\mathrm{b}}$ \\
\cline { 2 - 5 } & Residual & 318.203 & 30 & 10.607 & & \\
\cline { 2 - 5 } & Total & 633.333 & 32 & & & \\
\hline
\end{tabular}

a. Dependent Variable: Y

b. Predictor: (Constant), X2, X1

Source: Primary Data, Proceed (2020)

\subsection{The Influence of HR Competencies on Business Performance}

The t-test was used to determine the effect of each independent variable on the dependent variable. The effect of each variable can be seen by comparing the value of $t$ count with $t$ table with a significance level of 0.05 . If the value of $t$ count $>t$ table, the hypothesis which states that the independent variable has an effect on the dependent variable can be accepted. The $t$ table value can be obtained by looking at the table distribution at $\mathrm{DF}=\mathrm{N}-\mathrm{k}=33-3=30$, a significance of 0.05 then the $\mathrm{t}$ table is 1.697 .
Table 3. Result of t test

\begin{tabular}{|c|c|c|c|c|c|c|}
\hline \multicolumn{2}{|c}{ Model } & \multicolumn{2}{|c|}{$\begin{array}{c}\text { Unstandardized } \\
\text { Coefficients }\end{array}$} & $\begin{array}{c}\text { Standardized } \\
\text { Coefficients }\end{array}$ & \multirow{2}{*}{ t } & \multirow{2}{*}{ Sig. } \\
\cline { 2 - 5 } & B & $\begin{array}{c}\text { Std. } \\
\text { Error }\end{array}$ & Beta & & \\
\hline 1 & (Constant) & -6.321 & 5.484 & & -1.153 & 0.258 \\
\cline { 2 - 7 } & $\mathrm{X} 1$ & -0.063 & 0.230 & -0.069 & -0.272 & 0.787 \\
\cline { 2 - 7 } & $\mathrm{X} 2$ & 0.351 & 0.116 & 0.763 & 3.031 & 0.005 \\
\hline
\end{tabular}

a. Dependent variable: Y

Source: Primary Data, Proceed (2020)

In Table 3 the results of the t-test obtained the $t$ count value of -0.272 , the significance value of 0.787 . This shows that the HR Competencies variable (X1) has negative and insignificant effect on Business Performance (Y). The hypothesis which states that HR Competencies (X1) has a positive and significant effect on Business Performance (Y) is rejected. This study result did not support the results from $[16][17][23][25]$ research which state that HR competencies has a positive significant effect on business performance. The contradictive result of this study may caused by the characteristics of the Sasirangan business owners who do not all have the skills and abilities to produce Sasirangan. Some of them use the services of sasirangan fabric craftsmen. Others get the sasirangan to be marketed through the method of depositing goods from the sasirangan craftsmen. Others have capital capabilities so that they can obtain goods to be marketed by their businesses through the direct purchase method from craftsmen. In terms of business size, most business owners only have a small number of workers whose job is to run store administration and serve buyers, while for production workers they use are casual workers by utilizing the services of sasirangan fabric craftsmen. In addition, there is a tendency that high competent workers will stop working for Sasirangan MSMEs and start their own businesses.

\subsection{The Influence of Entrepreneurs' Skills on Business Performance}

In Table 3 the results of the t-test obtained the $t$ count value of 3.031, a significance value of 0.005 . This shows that the Entrepreneurs' Skills variable (X2) has a positive and significant effect on Business Performance (Y). The proof of this statement is based on the t-count value which is greater than the t-table value $(3.031>1.697)$ and the significant value is smaller than the significance level $(0.005<0.05)$. Based on the test results, the hypothesis which states that Entrepreneurs' Skills (X2) has a positive and significant effect on Business Performance (Y) is accepted. The results of this study illustrate that the 
Sasirangan business owners in these two industrial centres do have good entrepreneurs' skills. All Sasirangan business owners are Banjarese which known having good trading skills. There are some owners who start their business based on the urging of the craftsmen to open a shop to accommodate their products. The findings of this study are in line with the theory and research results of [5],[18],[24],[26],[27],[28]. which conclude Entrepreneurs' Skills had positive significant effect on Business Performance.

\section{CONCLUSION}

Some conclusions can be conveyed as follows:

1. HR competencies and Entrepreneurs' skills simultaneously have positive and significant impact on Sasirangan MSMEs' Business Performance in Banjarmasin Municipality.

2. HR competencies has a negative and insignificant effect on Sasirangan MSMEs' Business Performance in Banjarmasin Municipality.

3. Entrepreneurs' skills have a positive and significant impact on Sasirangan MSMEs' Business Performance in Banjarmasin Municipality.

\subsection{Suggestion}

The suggestions that can be formulated regarding the results of this study are:

1. Although HR Competencies are known to have negative insignificant effect on Sasirangan MSMEs' Business Performance, but according to the theory and results of previous research, HR competencies should be improved through MSMEs' employee dan owner participation in education and training programs in order to well-managed their busines.. The business owners should has his own ability to produce sasirangan so that they not too dependent on the current workforce. In addition, Sasirangan business owners can also provide free training \& guidance to teenagers and young people around their business environment so that later they can be recruited as casual workers if previous workers termination occurs.

2. Entrepreneurs' skills need to be maintained and improved through the participation of business owners in various training and coaching activities from relevant agencies and local governments in order to increase the ability to build their core business. Sasirangan entrepreneurs should expand their portfolio entreprenuers' skill such as Efficiency Orientation, Planning, Persuasiveness, Confidence, Organizational Awareness, Directing others, Teamwork, Leadership and Benchmarking.

3. Further research can further explore other factors that affect business performance. Other variables that also influence the success of MSMEs are seen from Business Performance antecedents such as: entrepreneurial intentions, interests, behavior, education and competencies.

4. In addition, further research may explore the effect of entrepreneurs skill antesedents and mediation role of entrepreneurs' skills to raise business performance and use different data analysis techniques such as SEM-PLS.

\section{AUTHORS' CONTRIBUTIONS}

Meiske Claudia and Rusniati contributed to the design and implementation of the research, to the analysis of the results and to the writing of the manuscript.

\section{ACKNOWLEDGMENTS}

This study was funded by a research grant from PNBP FEB ULM in 2019.

\section{REFERENCES}

[1] T. Tambunan. Upaya-upaya Meningkatkan Daya Saing Daerah [Internet]. 2006. Available from : www.kardin-indonesia.or.id.

[2] Y.S. Susilo, "Strategi Meningkatkan Daya Saing UMKM Dalam Menghadapi Implementasi CAFTA Dan MEA," Buletin Ekonomi., vol. 8, no. 2, pp. 70-170, 2010.

[3] M. D. Pushpakumari and T. Watanabe, "Do Strategies improve SME performance: an empirical analysis of Japan and Srilangka," Meijo Asean Research Journal., vol. 1, no. 1, pp. $61-75,2016$.

[4] I. Sidharta, and D. Lusyana. "Analisis Faktor Penentu Kompetensi Berdasarkan Konsep Knowledge, Skill, Dan Ability (KSA) Di Sentra Kaos Suci Bandung," Jurnal Computech \& Bisnis., vol. 8, no. 1, pp. 49-60, 2014.

[5] I.D.K.R. Ardiana, L. A. Brahmayanti, and Subaedi. Kompetensi SDM dan Pengaruhnya terhadap Kinerja UKM di Surabaya. Surabaya: 
Fakultas Ekonomi Universitas 17 Agustus 1945. 2010.

[6] Y.W. Astiti, Kewirausahaan "Pengaruh Pendidikan Berwirausaha Terhadap Motivasi Ekonomi Universitas Negeri Yogyakarta," Thesis, Fakultas Ekonomi, Universitas Negeri Yogyakarta, 2014.

[7] Wibowo, Manajemen Kinerja Edisi ke-3. Jakarta: Rajawali Press, 2012.

[8] L. Spencer and S. M. Spencer, Competencies at Work, Models for Superior Performance. Canada: John Wiley \& Sons, Inc. 1993.

[9] Moeheriono. Pengukuran Kinerja Berbasis Kompetensi. Jakarta: Raja Grafindo Persada, 2012.

[10] D. F. Spulber, "Journal of Economics and Management Strategy: Introduction," Journal of Economics and Management Strategy, vol. 13, no. 1, pp. 1-2, 2004.

[11] S.P. Robbins, Perilaku Organisasi (Buku 1). Jakarta: PT Indeks Kelompok Gramedia. 2003.

[12] A, Kurniawan, and Y. Yun, "Pengaruh Kompetensi Kewirausahaan dan Kelanggengan Usaha Terhadap Keunggulan Bersaing," Jurnal Inspirasi Bisnis dan Manajemen., Vol 2, (1), 2018, 65-78 e-2579-9401, p-2579-9312, 2018.

[13] A.Rusdiana, Kewirausahaan Teori dan Praktek. Cetakan ke 1. Bandung : CV. Pustaka Setia, 2014.

[14] S. Alfin, and L. Dwi, "Identifikasi Faktor-Faktor yang Mempengaruhi Kinerja UKM Catering di Kota Bandung." Jurnal Manajemen Teknologi., vol. 10, no. 2, 2011.

[15] H. Wijewardena, A.D. Zoysa, T. Fonseka, and B. Perera, "The impact of planning and control sophistication on performance of small and medium-sized enterprises: evidence from Sri Lanka," Journal of Small Business Management., vol. 42, no. 2, pp. 209-217, 2004.

[16] U. Hamzani, "The effect of Human Resources competencies and implementation of accounting information system on the performance of micro, small and medium enterprises," International Journal of Business, Economics and Law., vol. 19, no. 5, 2014.
[17] C.C.P. Paramitha. Pengaruh Kompentensi Individu, Orientasi Kewirausahaan dan Pesaing dalam Mencapai Keunggulan Bersaing melalui Kualitas Produk studi pada UKM Furnitur di Kota Semarang. Jakarta: Universitas 17 Agustus 1945. 2015.

[18] A. Irawan and H. Mulyadi, "Pengaruh Keterampilan Kewirausahaan Terhadap Keberhasilan Usaha (Studi Kasus pada Distro Anggota Kreative Independent Clothing Kommunitydi Kota Bandung)," Journal of Business Management and Enterpreneurship Education., vol. 1, no. 1, pp.213-223, 2016.

[19] F. Gerli, P. Gubitta, and A. Tognazzo, Entrepreneurial Competencies and Firm Performance: An Empirical Study Paper presented at the VIII International Workshop on Human Resource Management Conference Proceedings, Seville[Internet], 2019. Available from: https://www.researchgate. net/publication/ 228314296_Entrepreneurial_Competencies_and _Firm_Performance_An_Empirical_Study.

[20] A. Al Mamun, S.A. Fazal, and S. A. R. Muniandy, "Entrepreneurial knowledge, skills, competencies and performance: A study of micro-enterprises in Kelantan, Malaysia," Asia Pacific Journal of Innovation and Entrepreneurial., vol. 13, no. 1, pp. 29-48, 2019, doi : 10.1108/APJIE-11-2018-0067.

[21] M. S. Minai, S. Raza, N.A. Hashim, A.Y.M. Zain, and A.T. Tariq, "Linking Entrepreneurial Education with Firm Performance Through Entrepreneurial Competencies: A Proposed Conceptual Framework," Journal of Entrepreneurial Education., vol. 21, no. 4, 2016.

[22] Z. Asyifa, "Pengaruh Kompetensi Kewirausahaan Terhadap Kinerja Usaha (Studi Pada Usaha Mikro Di Kecamatan Ma'rang Kabupaten Pangkep)". Diploma thesis, Universitas Negeri Makassar, 2019.

[23] D. Wahyudiati, Pengaruh Aspek Keuangan Dan Kompetensi SDM (SDM) Terhadap Kinerja Usaha Mikro Kecil Dan Menengah (UMKM) Di Desa Kasongan. Skripsi, Universitas Negeri Yogyakarta, 2017.

[24] S. Sajilan, S. Tehseen and S. Adeyinka, "A Conceptual Framework of the Impact of Entrepreneurial Competencies on Small and Medium Enterprises Business Performance in 
the Malaysian Hospitality and Tourism Industry," Rev. Integr. Bus. Econ. Res., vol. 5, no. 2, pp. $47-61,2016$.

[25] I.M. Wardana and I.W. Utama, "The Role of Human Resource Competency on The Performance of SMEs in Enhancing Competitive Advantages: A Study of Endek Crafts in Klungkung Regency, Bali Province," International Journal of Economics, Commerce and Management., vol. 5, no. 11, 2017.

[26] R. Sembiring, "Impact of Human Resources' Knowledge and Skills on SMEs' in Medan City, Indonesia," International Journal of Management, Economics and Social Sciences., vol.5, no. 3, pp. 95-104, 2016.

[27] R. Hurriyati, G. Razati, S. Sulastri, and N.P. Putra, "Entrepreneur Skills on Business Performance of Small and Medium Enterprise," Advances in Economics, Business and Management Research., vol. 15, 2016.

[28] O. E. Abdul, "Entrepreneurial skills and growth of Small and Medium Enterprise (SMEs): A comparative analysis of Nigerian entrepreneurs and Minority entrepreneurs in the UK," International Journal of Academic Research in Business and Social Sciences., vol. 8, no. 5, pp. 28-46, 2018.

[29] W.G. Zikmund, B.J. Babin, J.C. Carr, and M. Griffin, Business Research Methods, South Western: Cengage Learning, 8th Edition. 2010.

[30] Sugiyono, Metode Penelitian Pendidikan Pendekatan Kuantitatif, Kualitatif, dan $R \& D$. Bandung: Alfabeta. 2010.

[31] I. Ghozali, Aplikasi Analisis Multivariete Dengan Program IBM SPSS 23 (Edisi 8). Cetakan ke VIII. Semarang: Badan Penerbit Universitas Diponegoro, 2016. 